\title{
Effect of growth retardants on intermittent irrigation during water deficit stress period in Mrig (Monsoon flowering) crop of Nagpur mandarin (Citrus reticulata Blanco)
}

\section{RK Jhade, AD Huchche, SK Pandey \& AK Verma}

Journal of Agriculture and Ecology

Volume-12 (December, 2021) ISSN: $2456-9410$

\section{Journal of}

Agriculture and

ISSN: $2456-9410$

Volume: 12

Journal of Agriculture and Ecology (2021) 12: 80-87 http://doi.org/10.53911/JAE.2021.12207 


\title{
Effect of growth retardants on intermittent irrigation during water deficit stress period in Mrig (Monsoon flowering) crop of Nagpur mandarin (Citrus reticulata Blanco)
}

\author{
RK Jhade ${ }^{1} \nabla$, AD Huchche ${ }^{2}$, SK Pandey ${ }^{3} \&$ AK Verma ${ }^{4}$ \\ ${ }^{1}$ JNKVV, Krishi Vigyan Kendra-II, Tamia, Chhindwara (M.P) 480559 \\ ${ }^{2}$ ICAR-Central Citrus Research Institute, Amravati Road, Nagpur, Maharashtra, India-440 033 \\ ${ }^{3}$ Dept. of Horticulture, JNKVV, Jabalpur, M.P. 482004 \\ ${ }^{4}$ ICAR-CIAH, Bikaner-334006, Rajasthan, India \\ Corresponding author: RK Jhade, Email: jhaderk49@gmail.com
}

\begin{tabular}{l}
\hline Article Info \\
\hline \\
Article history \\
Received: 10 November 2021 \\
Accepted: 28 December 2021 \\
Available online: 31 December \\
2021
\end{tabular}

\section{Key Words:}

Growth retardants, flowering, intermittent irrigation, soil moisture, leaf water potentia.

\begin{abstract}
A field investigation was carried out at the experimental orchard of Nagpur mandarin (Citrus reticulata Blanco) at CCRI, Nagpur in block no. 44 during 2015. Breaking the seasonality of Nagpur mandarin for commercial production would not only substitute the import of fresh fruits, but also provide the incentive prices to the Nagpur mandarin growers. Withholding water, root exposure and root pruning are the common practices adopted to regulate flowering. In the recent years, chlormequat chloride and paclobutrazol, growth retardants have been used with considerable success to induce early flowering for off-season production in several fruit crops. Citrus trees are exposed to water deficit stress by withholding water for about 30-45 days before expected flowering. Many times this stress is untimely broken due to climate change related untimely rains resulting in to sparse or no flowering due loss of flowering stimulus due to untimely rains. Therefore, to assess the effectiveness of two plant growth regulators chlormequat chloride and paclobutrazol these studies were conducted. Flood irrigation was given during the stress period in second week of May and following treatments were applied to reimpose the stress broken by intermittent irrigation. Six years old trees of Nagpur mandarin were used as experimental plants. The trees were uniform in age and size and trained to single stem. The trees were grown under drip irrigation following common cultural practices during the study period. The experiment was laid out in randomized block design with seven treatments replicated four times. Four trees were used for each replication. The treatments were imposed four months before flowering (June). The treatments tried were chlormequat chloride 2000, 3000 and $4000 \mathrm{ppm}$ as foliar spray, paclobutrazol $6 \mathrm{~g}, 9 \mathrm{~g}$ and $12 \mathrm{~g}$ as soil application along with control. Observations on soil moisture content (\%) at weekly interval, leaf water potential $\left(\Psi_{\mathrm{L}}\right)$ at weekly interval, orchard microclimate: temperature, humidity and rainfall, were recorded. Paclobutrazol $12 \mathrm{~g}$ showed the peak water stress in terms of leaf water potential $\left(\Psi_{\mathrm{L}}\right)$ which ranged from $(-3.00 \mathrm{MPa}$ to -3.17 $\mathrm{MPa})$ till mid June and there was no flowering in June-July due to the high temperature $\left(41.28^{\circ} \mathrm{C}\right)$, low rainfall $(6 \mathrm{~mm})$ and low humidity $(40.71 \%)$ during this period. The conditioning of microclimate in the orchard with sprinklers and irrigation can help in exploiting the flowering potential attained through growth retardant treatments.
\end{abstract}

\footnotetext{
Copyright ( 2021 Jhade et al., This is an open access article published under the terms of the Creative Commons Attribution License, which permits unrestricted use, distribution, and reproduction in any medium, provided the original work is properly cited.

Preferred citation: Jhade RK, Huchche, AD, Pandey SK \& Verma AK. 2021. Effect of growth retardants on intermittent irrigation during water deficit stress period in Mrig (Monsoon flowering) crop of Nagpur mandarin (Citrus reticulata Blanco). Journal of Agriculture and Ecology, 12: 80-87; http://doi.org/10.53911/JAE.2021.12207.
} 


\section{Introduction}

Citrus is an important genus of the family Rutaceae in the plant kingdom. It occupies a place of considerable importance in the fruit economy of the country and comprises the third largest fruit industry. The most important commercial citrus cultivars in India are the mandarins, followed by Sweet orange and acid limes. Nagpur mandarin (Citrus reticulata Blanco) is considered to be one of the most important cultivated species among citrus and is being commercially grown in Central India; this crop occupies the first position among the citrus in India with respect to area and production. Nagpur mandarin is the principal citrus fruit grown commercially in Central India covering an area of 0.135 million ha with an estimated production of 7.4 million tonnes and productivity 5.5 MT/HA. (NHB 2014). Flowering is an important step in fruit production. The price of fruit depends on market demand, so therefore, induction of flowering at certain times is necessary. The flowers of Nagpur mandarin normally thrice in a year i.e., Ambia bahar (Jan-Feb), Mrig bahar (June-July) and Hasta bahar (Sep-Oct). Among all these Mrig crop which comes to harvest during summer (March) gets highest remunerative price. Breaking the seasonality of Nagpur mandarin for commercial production would not only substitute the import of fresh fruits, but also provide the incentive prices to the Nagpur mandarin growers. Withholding water, root exposure and root pruning are the common practices adopted to regulate flowering. In the recent years, chlormequat chloride and paclobutrazol, growth retardants have been used with considerable success to induce early flowering for off-season production in several fruit crops Therefore, the present study was undertaken to determine the effectiveness of growth retardants such as chlormequat chloride and paclobutrazol of application in inducing flowering for off-season production of Nagpur mandarin under Central India conditions.

Flower expression in Mrig crop is more dependent on the prevailing weather conditions as described above in the absence of which there is risk of total crop failure leading to uncertainties in taking sustainable returns from the orchard. Many times, it happens that there are pre-monsoon rains or untimely rains of significant magnitude to the extent of $20-30 \mathrm{~mm}$ or more due to cyclonic disturbances in the Arabian Sea or Bay of Bengal which result in to untimely breakage of water deficit stress followed by normal summer temperatures with low humidity. Such plants fail to initiate flowering in JuneJuly. Therefore, to offset the ill effects of these untimely rains it is necessary to reimpose the physiological (abiotic) stress with growth retardant (anti-gibberellin) induced stress. With this concept in mind this study was conducted by involving intermittent irrigation as substitute for untimely rains and use of growth retardants paclobutrazol and chlormequat chloride.

Paclobutrazol [(2RS,3RS)-1-(4chlorophenyl)-4,4-dimethyl-2-(1H-1,2,4 triazol-1-yl) pentan-3-ol (Trade name Luster)] is one of growth retardant which inhibits kaurene oxidase and thus blocks the oxidative reactions from ent-kaurene to entkaurenoic acid in the pathway leading to gibberellic acid. The mode of action of PBZ 
has been associated with a decrease in transpiration, plant height, biomass and leaf area and increase in stomatal resistance. In case of induction of organ formation, there still have little attention. Soil application of paclobutrazol enhanced subsequent flowering but decreased new shoot sprouting and growth. The PBZ response in flowering induction under non inductive conditions, such as the occurrence of drought stress in period before flowering, can be variable due to factors pertaining to concentrations used, the absorption and the plant developmental stage at time of product application (Goldschimidt et al. 1998). Chlormequat chloride [(2-chloroethyltrimethylammonium chloride) (Trade name-Lihocin)] is also one of the retardants of plant Growth. It processes against gibberellic acid inside the plant when absorbed by organs (root, stem and leaves). The mode of action of CCC has been associated with it is absorbed by the leaves and acts on developing stem, shortening and thicking of internodes by inhibiting the cell elongations, restrain the elongation of cells, but have no influence on cell division; Restrain the growth of stem and leaves without affecting the development of sexual organs. It can make the plant short but strong with gathered trunk; Make the leaves darker and thicker and increase the ability to resist collapse, drought, cold and alkaline. The reasons for the irregular flowering behaviour are not yet fully understood and, therefore, attempts were made to study the problem of irregular flowering from several angles. The studies conducted at the National Research Centre for Citrus on the use of growth regulators like Chlormequat chloride up to 4000 ppm (Dass et al. 1991)

\section{Materials and Methods}

This study was conducted at the Institute's experimental farm in Nagpur mandarin block no. 44. The experiment was laid out in randomized block design with seven treatments replicated four times. Four trees were used for each replication. The treatments were imposed four months before flowering (June). A total of eight years old 112 trees of Nagpur mandarin budded on rough lemon with $6 \times 6 \mathrm{~m}$ spacing with similar vigour were selected to investigate the effect of chlormequat chloride (CCC) and paclobutrazol (PBZ) on monsoon flowering of Nagpur mandarin. The treatments tried were T1- Chlormequat chloride 2000 ppm as foliar spray, T2- Chlormequat chloride 3000 ppm as foliar spray, T3- Chlormequat chloride 4000 ppm as foliar spray, T4 - Paclobutrazol $6 \mathrm{~g}$ as soil application, T5- Paclobutrazol 9g as soil application, T6- Paclobutrazol 12g as soil application, T7- Control. Six years old trees of Nagpur mandarin were used as experimental plants. The trees were uniform in age and size and trained to single stem. The trees were grown under drip irrigation following common cultural practices during the study period. These trees had set fruits by the end of February 2015 (spring flowering crop, Ambia bahar) which were defruited one month after fruit set in the first week of April when the fruits were of marble size (30 to $50 \mathrm{~mm}$ diameter).

Soil moisture stress was imposed from 16.5.2015 and intermittent irrigation @90 litres/plant to all experimental plants along with foliar application of chlormequat chloride 
(2000, 3000 and 4000 ppm) and soil application of paclobutrazol (6, 9 and 12 g/plant) was given on 21.5.2015. Second intermittent irrigation was given on 30.5.2015 @ 90 litres/ plant. Leaf sampling for hormone analysis was done before and after the imposition of water stress and growth retardants on 15th May and 15th June, 2015 respectively. Observations of soil moisture content at weekly interval, Leaf water potential (LWP), Soil moisture content (\%) during at weekly interval, till July 2015. Weather data was recorded in May-July 2015 (Table 1). Orchard microclimate: temperature, humidity and rainfall of each treatment were recorded.

Table 1. Weather data at CCRI and IMD, Nagpur during experimental period-2015

\begin{tabular}{|c|c|c|c|c|c|c|c|c|c|}
\hline \multicolumn{6}{|c|}{ Experimental site at ICAR-CCRI } & \multicolumn{4}{|c|}{ Nagpur airport (IMD) } \\
\hline \multirow{2}{*}{ MW } & \multirow{2}{*}{ Date } & \multicolumn{2}{|c|}{$\begin{array}{c}\text { Temperature } \\
\left({ }^{\circ} \mathrm{C}\right)\end{array}$} & \multirow{2}{*}{$\begin{array}{l}\text { RH } \\
(\%)\end{array}$} & \multirow{2}{*}{$\begin{array}{c}\text { Rainfall } \\
\text { (mm) }\end{array}$} & \multicolumn{2}{|c|}{$\begin{array}{c}\text { Temperature } \\
\left({ }^{\circ} \mathrm{C}\right)\end{array}$} & \multirow[t]{2}{*}{$\begin{array}{l}\mathrm{RH} \\
(\%)\end{array}$} & \multirow[t]{2}{*}{$\begin{array}{c}\text { Rainfall } \\
\text { (mm) }\end{array}$} \\
\hline & & Max. & Min. & & & Max. & Min. & & \\
\hline 21 & 21-27 May & 44.91 & 27.89 & 54.79 & 0 & 39.66 & 25.01 & 34.14 & 0.00 \\
\hline 22 & 28 - 3 June & 43.40 & 26.10 & 62.42 & 0 & 44.77 & 27.53 & 44.5 & 2.00 \\
\hline 23 & 4 -10 June & 34.17 & 26.08 & 58.00 & 0 & 29.34 & 19.34 & 40.71 & 6.00 \\
\hline 24 & 11-17 June & 37.36 & 25.28 & 65.9 & 47.3 & 32.40 & 22.23 & 67.71 & 146.00 \\
\hline 25 & 18-24 June & 32.43 & 23.81 & 76.00 & 113 & 27.53 & 20.27 & 77.86 & 241.00 \\
\hline 26 & 25 June - 1 July & 33.53 & 23.63 & 61.75 & 8.5 & 34.77 & 24.71 & 81.29 & 10.00 \\
\hline 27 & 2 - 8 July & 33.48 & 23.52 & 61.75 & 13.4 & 35.13 & 24.80 & 69.43 & 2.00 \\
\hline 28 & $9-15$ July & 33.9 & 24.32 & 71.3 & 0 & 29.29 & 21.57 & 69.86 & 9.00 \\
\hline 29 & $16-22$ July & 32.08 & 24.16 & 70.4 & 0 & 22.99 & 18.10 & 60.57 & 5.00 \\
\hline 30 & $23-29$ July & 30.96 & 23.66 & 76.25 & 69.2 & 26.70 & 20.03 & 75.43 & 34.00 \\
\hline \multicolumn{5}{|c|}{ Chlormequat chloride (50\% SL) } & \multicolumn{2}{|c|}{ Paclobutrazol } & $(2 \mathrm{RS}$, & \multicolumn{2}{|c|}{$3 R S)-1-(4-$} \\
\hline \multicolumn{5}{|c|}{$\begin{array}{l}\text { Chlormequat chloride }(50 \%) \text { (2- } \\
\text { chloroethyltrimethylammonium chloride), a } \\
\text { plant growth retardant (an anti-gibberellin } \\
\text { compound) locally available in the market was } \\
\text { used as a source of CCC. }\end{array}$} & \multicolumn{5}{|c|}{$\begin{array}{l}\text { chlorophenyl)-4,4-dimethyl-2-(1H- } \\
\text { 1,2,4triazol-1-yl) pentan-3-ol) a plant growth } \\
\text { retardant (an anti-gibberellin compound) } \\
\text { locally available in the market was used as a } \\
\text { source of paclobutrazol. }\end{array}$} \\
\hline
\end{tabular}

\section{Paclobutrazol $(28 \% \mathrm{~W} / \mathrm{W}$ SC $30 \% \mathrm{~W} / \mathrm{V})$}

Table 2. Details of treatments combinations and application methods

\begin{tabular}{clccc}
\hline Treatments & \multicolumn{1}{c}{$\begin{array}{c}\text { Plant growth } \\
\text { Retardants }\end{array}$} & Concentration & $\begin{array}{c}\text { Quantity used of the } \\
\text { commercially } \\
\text { available } \\
\text { formulation per } \\
\text { plant }\end{array}$ & $\begin{array}{c}\text { Application } \\
\text { method }\end{array}$ \\
\hline $\mathrm{T}_{1}$ & Chlormequat chloride & $2000 \mathrm{ppm}$ & $4 \mathrm{ml}$ & Foliar spray \\
$\mathrm{T}_{2}$ & Chlormequat chloride & $3000 \mathrm{ppm}$ & $6 \mathrm{ml}$ & Foliar spray \\
$\mathrm{T}_{3}$ & Chlormequat chloride & $4000 \mathrm{ppm}$ & $8 \mathrm{ml}$ & Foliar spray \\
$\mathrm{T}_{4}$ & Paclobutrazol & $6 \mathrm{~g}$ & $21.43 \mathrm{~g}$ & Soil application \\
& & 83 & &
\end{tabular}


he//saaer.org.in

$\begin{array}{clccc}\mathrm{T}_{5} & \text { Paclobutrazol } & 9 \mathrm{~g} & 32.14 \mathrm{~g} & \text { Soil application } \\ \mathrm{T}_{6} & \text { Paclobutrazol } & 12 \mathrm{~g} & 42.85 \mathrm{~g} & \text { Soil application } \\ \mathrm{T}_{7} & \text { Control } & - & - & -\end{array}$

\section{Leaf water potential}

The leaf water potential (LWP) was measured using a pressure chamber (PSYPRO Water Potential System., WESCOR, Logan, USA). Two fully expanded leaves at the fourth position around the canopy of each experimental tree were sampled. LWP was measured during at weekly interval of experiment till experiment completion.

\section{Soil moisture content}

Soil moisture was determined using a gravimetric method and soil samples were taken on the same dates as the LWP measurements at weekly interval. Clean and dry the weighing tin+lid and weigh (W1). Select a representative quantity of moist soil in the amount specified by a test. Place the sample in the weighing tin+lid, the tin and contents (W2). place the tin with contents and lid in the oven and dry to constant weight between $105^{\circ} \mathrm{C}$ and $110^{\circ} \mathrm{C}$ for $24 \mathrm{hr}$. Remove the tin with contents from the oven, and place the whole in the desiccator to cool. Weigh the tin+lid and contents to (W3).

Calculate the moisture content of the soil as a percentage of the dry soil weight.

Table 3. Leaf water potential $(\mathrm{MPa})$ and soil moisture content $(\%)$ during experimentation

\begin{tabular}{lcccccccc}
\hline Date & \multicolumn{2}{c}{$27-05-2015$} & \multicolumn{2}{c}{$03-06-2015$} & \multicolumn{2}{c}{$10-06-2015$} & \multicolumn{2}{c}{$17-06-2015$} \\
\hline \multirow{2}{*}{ Parameters } & MC & LWP & MC & LWP & MC & LWP & MC & $\begin{array}{c}\text { LWP } \\
(\%)\end{array}$ \\
& $(\mathrm{MPa})$ & $(\%)$ & $(\mathrm{MPa})$ & $(\%)$ & $(\mathrm{MPa})$ & $(\%)$ & $(\mathrm{MPa})$ \\
\hline CCC 2000ppm & 6.99 & -3.19 & 7.17 & -3.01 & 7.07 & -3.00 & 10.12 & -2.81 \\
CCC 3000ppm & 7.18 & -3.01 & 6.75 & -3.17 & 7.00 & -3.00 & 10.49 & -2.84 \\
CCC 4000ppm & 7.02 & -3.00 & 6.30 & -3.13 & 7.42 & -3.04 & 9.01 & -2.80 \\
PBZ 6g/tree & 7.45 & -3.04 & 6.53 & -3.15 & 7.65 & -3.06 & 10.54 & -2.85 \\
PBZ 9g/tree & 6.43 & -3.14 & 6.11 & -3.11 & 7.76 & -3.07 & 9.04 & -2.80 \\
PBZ 12g/tree & 6.39 & -3.13 & 6.40 & -3.14 & 7.54 & -3.05 & 9.95 & -2.89 \\
Control & 7.41 & -3.04 & 6.89 & -3.18 & 7.77 & -3.07 & 10.12 & -2.81 \\
CD at 5\% & 0.23 & 0.12 & 0.22 & 0.11 & 0.25 & 0.10 & 0.41 & 0.10 \\
\hline
\end{tabular}

$\mathrm{MC} \%=\mathrm{W} 2-\mathrm{W} 3 / \mathrm{W} 3-\mathrm{W} 1 \times 100$

Where:

$\mathrm{W} 1=$ Weight of tin $(\mathrm{g})$

$\mathrm{W} 2=$ Weight of moist soil + tin $(\mathrm{g})$

$\mathrm{W} 3=$ Weight of dried soil + tin $(\mathrm{g})$

\section{Results and Discussion}

Soil physical properties and nutrient status

The soil physico-chemical properties of the experimental plants were determined for various important parameters as detailed in table 3. The soil physical properties were estimated as $\mathrm{pH}$ (7.88 to 8.28), electrical conductivity $(0.230 \mathrm{dS} / \mathrm{m}$ to $0.324 \mathrm{dS} / \mathrm{m})$, organic carbon $(0.59 \%$ to $1.43 \%)$ and $\mathrm{CaCO}_{3}$ (1.54 to 4.03$)$. The soil available nutrients were analysed as nitrogen (from $137.98 \mathrm{~kg} / \mathrm{ha}$ to $200.7 \mathrm{~kg} / \mathrm{ha})$, phosphorus $(14.49 \mathrm{~kg} / \mathrm{ha}$ to $79.00 \mathrm{Kg} / \mathrm{ha})$ and potassium $(519.4 \mathrm{~kg} / \mathrm{ha}$ to $991.1 \mathrm{~kg} / \mathrm{ha}$ ) in various treatments in experimental orchard. The status of total soil micronutrients varied as $\mathrm{Fe}(9.56 \mathrm{ppm}$ to $17.84 \mathrm{ppm}), \mathrm{Mn}$ (54.37 ppm to $74.56 \mathrm{ppm}$ ), $\mathrm{Cu}$ (4.40 ppm to $8.75 \mathrm{ppm}$ ) and $\mathrm{Zn}$ (0.84 to $1.74 \mathrm{ppm})$. 
Table 3. Cont....

\begin{tabular}{|c|c|c|c|c|c|c|c|c|c|c|c|}
\hline \multirow{2}{*}{\multicolumn{2}{|c|}{$\begin{array}{l}\text { Date } \\
\text { Parameters }\end{array}$}} & \multicolumn{3}{|c|}{ 24-06-2015 } & \multicolumn{2}{|c|}{$01-07-15$} & \multicolumn{3}{|c|}{ 08-07-2015 } & \multicolumn{2}{|c|}{$15-07-15$} \\
\hline & & $\begin{array}{l}\mathrm{MC} \\
(\%)\end{array}$ & $\begin{array}{r}\mathrm{LV} \\
(\mathrm{M}\end{array}$ & & $\begin{array}{l}\mathrm{MC} \\
(\%)\end{array}$ & $\begin{array}{c}\text { LWP } \\
(\mathrm{MPa})\end{array}$ & $\begin{array}{l}\mathrm{MC} \\
(\%)\end{array}$ & \multicolumn{2}{|c|}{$\begin{array}{c}\text { LWP } \\
(\mathrm{MPa})\end{array}$} & $\begin{array}{l}\mathrm{MC} \\
(\%)\end{array}$ & $\begin{array}{c}\text { LWP } \\
(\mathrm{MPa})\end{array}$ \\
\hline \multicolumn{2}{|c|}{ CCC 2000ppm } & 14.96 & \multirow{2}{*}{\multicolumn{2}{|c|}{$\begin{array}{l}-2.49 \\
-2.48\end{array}$}} & 9.37 & -2.83 & 7.81 & \multicolumn{2}{|c|}{-3.08} & 12.23 & -2.62 \\
\hline \multicolumn{2}{|c|}{ CCC 3000ppm } & 14.83 & & & 9.40 & -2.84 & 8.62 & \multicolumn{2}{|c|}{-2.96} & 12.57 & -2.65 \\
\hline \multicolumn{2}{|c|}{ CCC 4000ppm } & 15.59 & \multicolumn{2}{|c|}{-2.45} & 9.96 & -2.89 & 8.57 & \multicolumn{2}{|c|}{-2.95} & 12.24 & -2.62 \\
\hline \multicolumn{2}{|c|}{ PBZ 6g/tree } & 14.72 & \multicolumn{2}{|c|}{-2.47} & 9.40 & -2.84 & 8.33 & \multicolumn{2}{|c|}{-2.93} & 10.90 & -2.89 \\
\hline \multicolumn{2}{|c|}{ PBZ 9g/tree } & 13.78 & \multicolumn{2}{|c|}{-2.57} & 8.98 & -2.99 & 7.98 & \multicolumn{2}{|c|}{-3.09} & 10.03 & -2.80 \\
\hline \multicolumn{2}{|c|}{ PBZ $12 \mathrm{~g} /$ tree } & 13.04 & \multicolumn{2}{|c|}{-2.50} & 8.30 & -2.93 & 7.34 & \multicolumn{2}{|c|}{-3.03} & 12.34 & -2.63 \\
\hline \multicolumn{2}{|l|}{ Control } & 14.80 & \multicolumn{2}{|c|}{-2.48} & 8.66 & -2.96 & 8.43 & \multicolumn{2}{|c|}{-2.94} & 13.79 & -2.57 \\
\hline $\mathrm{CD}$ at $5 \%$ & & 0.32 & \multicolumn{2}{|c|}{0.10} & 0.38 & 0.10 & 0.29 & \multicolumn{2}{|c|}{0.13} & 0.40 & 0.11 \\
\hline \multicolumn{6}{|c|}{$\begin{array}{l}\text { The leaf nutrient status of the experimental } \\
\text { plants was determined before imposition of } \\
\text { treatments for various important parameters as } \\
\text { detailed in table } 4 \text {. The leaf available nutrients } \\
\text { were analysed as nitrogen ( } 0.685 \% \text { to } 2.155 \\
\text { Table 4. Soil physical properties and nutrient st }\end{array}$} & \multicolumn{6}{|c|}{$\begin{array}{l}(\%) \text {, phosphorus }(0.016 \% \text { to } 0.054 \%) \text { and } \\
\text { potassium }(0.73 \% \text { to } 1.75 \%) \text { in various } \\
\text { treatments in experimental orchard. The status } \\
\text { of total leaf micronutrients varied as Fe } \\
\text { (221.65 ppm to } 690.55 \mathrm{ppm}) \mathrm{Mn}(25.01 \mathrm{ppm} \\
\text { to } 55.45 \mathrm{ppm}) \mathrm{Cu}(6.6 \mathrm{ppm} \text { to } 13.65 \mathrm{ppm}) \text { and } \\
\mathrm{Zn}(36.3 \text { to } 41.1 \mathrm{ppm}) \text {. }\end{array}$} \\
\hline Treatments & $\mathrm{pH}$ & $\mathrm{EC}$ & $\begin{array}{r}\mathrm{OC} \\
(\%) \\
\end{array}$ & $\mathrm{CaCO}_{3}$ & $\begin{array}{c}\mathrm{N} \\
(\mathrm{kg} / \mathrm{ha}) \\
\end{array}$ & $\begin{array}{c}\mathrm{P} \\
(\mathrm{kg} / \mathrm{ha})\end{array}$ & $\begin{array}{c}\mathrm{K} \\
(\mathrm{kg} / \mathrm{ha})\end{array}$ & $\begin{array}{c}\mathrm{Fe} \\
(\mathrm{ppm})\end{array}$ & $\begin{array}{c}\mathrm{Mn} \\
\text { (ppm) }\end{array}$ & $\begin{array}{c}\mathrm{Cu} \\
(\mathrm{ppm})\end{array}$ & $\begin{array}{r}\mathrm{Zn} \\
(\mathrm{ppm})\end{array}$ \\
\hline $\begin{array}{l}\mathrm{T}_{1}-\mathrm{CCC} \\
2000 \mathrm{ppm}\end{array}$ & 8.28 & 0.280 & 1.40 & 4.03 & 163.07 & 71.53 & 519.4 & 9.56 & 54.37 & 4.65 & 1.747 \\
\hline $\begin{array}{l}\mathrm{T}_{2}-\mathrm{CCC} \\
3000 \mathrm{ppm}\end{array}$ & 8.14 & 0.303 & 1.43 & 3.32 & 150.53 & 79.00 & 754.6 & 14.43 & 68.87 & 6.09 & 2.11 \\
\hline $\begin{array}{l}\mathrm{T}_{3}-\mathrm{CCC} \\
4000 \mathrm{ppm}\end{array}$ & 7.88 & 0.324 & 1.23 & 3.91 & 200.70 & 67.80 & 975.6 & 8.59 & 74.56 & 5.79 & 1.68 \\
\hline $\begin{array}{l}\mathrm{T}_{4}-\mathrm{PBZ} 6 \\
\mathrm{~g} / \text { tree }\end{array}$ & 7.93 & 0.243 & 0.606 & 1.54 & 181.88 & 26.66 & 991.1 & 13.55 & 57.187 & 4.59 & 0.84 \\
\hline $\begin{array}{l}\mathrm{T}_{5}-\mathrm{PBZ} 9 \\
\mathrm{~g} / \text { tree }\end{array}$ & 8.13 & 0.262 & 0.686 & 3.43 & 163.07 & 14.49 & 522.2 & 15.47 & 68.93 & 4.4 & 1.17 \\
\hline $\begin{array}{l}\mathrm{T}_{6}-\mathrm{PBZ} \\
12 \mathrm{~g} / \text { tree }\end{array}$ & 7.96 & 0.291 & 0.829 & 3.32 & 181.88 & 33.60 & 775.6 & 17.84 & 69.93 & 5.51 & 1.56 \\
\hline $\mathrm{T}_{7}$-Control & 7.89 & 0.230 & 0.59 & 3.08 & 137.98 & 67.87 & 931.0 & 15.36 & 74.125 & 8.75 & 1.33 \\
\hline $\mathrm{CD}$ at $5 \%$ & 0.203 & 0.013 & 0.063 & 0.125 & 2.56 & 7.75 & 4.86 & 0.213 & 1.039 & 0.098 & 0.120 \\
\hline
\end{tabular}

Leaf nutrient status of experimental plants after imposition of growth retardant treatment

The leaf nutrient status of the experimental plants was determined after imposition of treatments for various important parameters as detailed in table 4 . The leaf available nutrients were analysed as nitrogen (1.2\% to $2.28 \%)$, phosphorus $(0.0158 \%$ to $0.0104 \%)$ and potassium (1.315\% to $1.725 \%)$. The status of total leaf micronutrients varied as $\mathrm{Fe}$ (311.6 ppm to $702.75 \mathrm{ppm}), \mathrm{Mn}$ (29.25 ppm to 44.1 $\mathrm{ppm}), \mathrm{Cu}$ (14.8 ppm to $33.8 \mathrm{ppm}$ ), and $\mathrm{Zn}$ (33.45 to $38.4 \mathrm{ppm}$ ) in various treatments in experimental orchard. The quantum of rains received in June was $160 \mathrm{~mm}$ (normal 163 $\mathrm{mm}$ ) with maximum temperatures of around 32 to $370 \mathrm{C}$, minimum temperatures of around 
23 to $26{ }^{\circ} \mathrm{C}$ and $\mathrm{RH}$ of $58-76 \%$ in the month of June whereas in the month of July only 90 $\mathrm{mm}$ rains were received as against a normal of $304 \mathrm{~mm}$. Only vegetative growth flushes were observed and no flowering was observed till the end of July, 2015. This could be due to continuous dry spell with scanty rains in the month of July.

Flower expression in Mrig crop is more dependent on the prevailing weather conditions as described above in the absence of which there is risk of total crop failure leading to uncertainties in taking sustainable returns from the orchard. Many times, it happens that there are pre-monsoon rains or untimely rains of significant magnitude to the extent of $20-30 \mathrm{~mm}$ or more due to cyclonic disturbances in the Arabian sea or Bay of Bengal which result in to untimely breakage of water deficit stress followed by normal summer temperatures with low humidity. Such plants fail to initiate flowering in JuneJuly. Therefore, to offset the ill effects of these untimely rains it is necessary to reimpose the physiological (abiotic) stress with growth retardant (anti-gibberellin) induced stress. With this concept in mind this study entitled "Effect of growth retardants on intermittent irrigation during water deficit stress period in Mrig (Monsoon flowering) crop of Nagpur mandarin" was initiated at the Institute's experimental farm in Nagpur mandarin block no. 44. These trees had set fruits by the end of February 2015 (spring flowering crop, Ambia bahar) which were defruited one month after fruit set in the first week of April when the fruits were of marble size (30 to $50 \mathrm{~mm}$ diameter). Soil moisture stress, intermittent irrigation with imposed treatment at this period. The quantum of rains received in June was $160 \mathrm{~mm}$ (normal 163 $\mathrm{mm}$ ) with maximum temperatures of around 32 to $37{ }^{\circ} \mathrm{C}$, minimum temperatures of around 23 to $26{ }^{\circ} \mathrm{C}$ and $\mathrm{RH}$ of $58-76 \%$ in the month of June whereas in the month of July only 90 $\mathrm{mm}$ rains were received as against a normal of $304 \mathrm{~mm}$. Only vegetative growth flushes were observed and no flowering was observed till the end of July, 2015. This could be due to continuous dry spell with scanty rains in the month of July and due to less soil available phosphorus $(0.55 \mathrm{~kg} / \mathrm{ha}$ to $3.3 \mathrm{~kg} / \mathrm{ha})$ as against a normal of (13 to $22 \mathrm{~kg} / \mathrm{ha}$ ) and sub optimal leaf phosphorus status $(0.0158 \%$ to $0.0104 \%)$ as against a normal of (0.07 to 0.09 $\%)$.

\section{Conclusion}

The leaf $\mathrm{GA}_{3}$ levels in all the growth retardant treatments decreased significantly one month after imposition of CCC and paclobutrazol. It was least in paclobutrazol $12 \mathrm{~g} /$ tree $(185.2 \mathrm{ng} / \mathrm{g})$ and CCC $4000 \mathrm{ppm}$ $(157.9 \mathrm{ng} / \mathrm{g})$ whereas in control trees it remained about the same $(351.70 \mathrm{ng} / \mathrm{g})$ as before application of treatments $(341.92 \mathrm{ng} / \mathrm{g})$. Only vegetative growth flushes were observed and no flowering was observed till the end of July month. This could be due to continuous dry spell with scanty rains in the month of July (90 $\mathrm{mm}$ as against a normal of $304 \mathrm{~mm}$ ) and less soil available and leaf phosphorus status.

\section{References}

Ballester C, Intrigliolo D \& Castel JR. 2011. Response of Clementina de Nules citrus trees to summer deficit irrigation. Yield components and fruit composition. Agricultural Water Management, 98: 1027-1032. 
Ballester C et al. 2008. Effects of regulated deficit irrigation on 'Clementina de Nules' and 'Navel Lane Late' Citrus Trees: Growth, Yield and Fruit quality. Proceedings of International society of citriculture. The $11^{\text {th }}$ International citrus congress. Wuhan, China Vol-I 749-753.

Goldschmidt EE, Tamim M \& Goren R. 1998. Gibberellins and flowering in citrus and other fruit trees. Acta Horticulturae, 1(464):201-216.

Huchche et al. 2008. Water deficit stress regulated flowering in Nagpur mandarin (Citrus reticulate Blanco) In: Proceedings of International society of citriculture. The $11^{\text {th }}$ International citrus congress. Wuhan, China Vol-I.

Lolaei A, Mobasheri S, Bemana R \& Teymori N. 2013. Role of Paclobutrazol on Vegetative and Sexual Growth of Plants. International Journal of Agriculture and Crop Science, 5-9:958-961.
Martinez-Fuentes A, Mesejo C, Munoz Fambuena N \& Reig C. 2013. Fruit load restricts the flowering promotion effect of paclobutrazol in alternate bearing Citrus spp. Scientia Horticulturae, 151: 122-127.

Phadung T, Krisanapook K \& Phavaphutanon L. 2011. Paclobutrazol, Water Stress and Nitrogen Induced Flowering in 'Khao Nam Phueng' Pummelo. Kasetsart J. (Nat. Sci.) 45:189 - 200.

Standards Association of Australia. AS 1289 B1.1-1977. Determination of the Moisture Content of a Soil: Oven Drying Method (standard method).

Tripathi KM \& Dhakal DD. 2005. Effect of paclobutrazol on off-season flower induction in acid lime (Citrus aurantifolia Swingle) landraces under chitwan condition. J. Inst. Agric. Anim. Sci., 26:8792. 